\title{
Quality of raw milk collected from Mymensingh town in Bangladesh
}

\author{
Uddin MS', MR Habib², MA Islam², S Afrin'², MH Rashid ${ }^{2 *}$ \\ ${ }^{1}$ Upazila Family Planning Officer, Bajitpur, Kishoregonj; ${ }^{2}$ Department of Dairy Science, Bangladesh Agricultural \\ University, Mymensingh-2202, Bangladesh
}

\begin{abstract}
The present study was conducted to know the chemical qualities and adulteration of fresh raw milk collected from local markets (Bhangnamari bazaar, Sutiakhali bazaar, Vabokhali bazaar, Shombhuganj bazaar and Mymensingh sadar bazaar) of Mymensingh sadar, Bangladesh. Milk samples were analyzed for chemical parameters (contents of acidity, total solids, solids-not-fat, fat, protein and ash) and adulteration (presence of formalin, sugar or starch). Also, lactometer reading was recorded to monitor the specific gravity of the collected milk samples. Result showed that the specific gravity of milk from different sources differed non-significantly. The total solids, fat and protein contents of all the samples were in normal range except the milk fat content collected from Shombhuganj bazaar (32.66 \pm 4.04 $\mathrm{g} / \mathrm{Kg})$ and Mymensingh sadar bazaar $(30.66 \pm 4.51 \mathrm{~g} / \mathrm{Kg})$ which had less $(\mathrm{p}<0.01)$ than the minimum legal standard of milk fat $(35.00 \mathrm{~g} / \mathrm{Kg})$. The solids-not-fat content of the milk samples collected from Bhangnamari bazaar $(72.93 \pm 8.78 \mathrm{~g} / \mathrm{Kg})$ and Vabokhali bazaar $(79.33 \pm 6.81 \mathrm{~g} / \mathrm{Kg})$ were less than that from Mymensingh sadar bazaar $(95.67 \pm 11.72 \mathrm{~g} / \mathrm{Kg})$. Developed acidity was detected in the samples

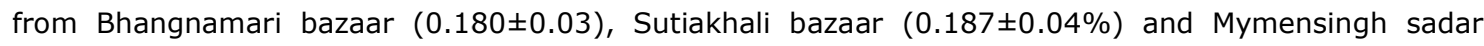
bazaar $(0.180 \pm 0.02 \%)$, while other samples were found to the fresh $(0.150-0.157 \%)$. All of the adulteration tests showed negative results. The results suggested that though there were some fluctuations in quality among the bazaars regarding the standard of parameters, the raw milk samples were of acceptable quality.
\end{abstract}

Key words: milk, quality, adulteration, acceptance

Bangladesh Animal Husbandry Association. All rights reserved. $\quad$ Bang. J. Anim. Sci. 2016. 45 (2): 73-78

\section{Introduction}

Milk is the nature's single most complete food $\left(\mathrm{O}^{\prime}\right.$ Mahony, 1988) and the cheapest source of nutrients which is easily accepted and used by the people of all age's in rural areas as well as urban areas. Milk contains on an average 87.25 (\%) water, $3.80(\%)$ fat, $3.50(\%)$ protein, 4.80 (\%) lactose and $0.7(\%)$ minerals. Beside these, milk contains considerable amounts of fat soluble vitamins namely vitamin-A, D, E \& K and water soluble vitamins such as vitamin-B complex \& vitamin-C (Eckles et al., 1951). The essential amino acids like tryptophan and lysine are present in large quantity in milk, which are deficient in vegetable protein. Milk protein requires for formation of new tissues, repair of broken down tissue and overall development of the body system. The constituents may vary with the breed, type of feed, stage of lactation, season, age of the cow, milking method and milking interval etc.
Quality milk means the milk which has normal chemical composition, has lower degree of titratable acidity with good flavour, completely free from sediment and extraneous substances, free from pathogenic bacteria and harmful toxic substances. Milk quality can be deteriorated due to unhygienic milk production, preservation technology and adulteration (Haasnoot et al., 2004). Adulteration is an act of intentionally debasing the quality of food which is offered for sale either by admixture or substitution of inferior substances or by the removal of some valuable ingredients (FDA, 1995). Adulterated food may be dangerous for health due to contain various toxic chemicals as well as it may be deficient of nutrients that are required for proper growth and development of human body (Marcus, 1979). Consumers always demand nutritionally enriched milk and milk products. Due to high consumption of milk and milk products, some unscrupulous milk producers have taken targets to add

*Corresponding author: mrashid_69@yahoo.com 
potential adulteration in milk to get more financial gains (Nicolaou et al., 2011).

Moreover, addition of soda, urea, formalin and melamine may deteriorate the milk quality and milk becomes unsafe for human consumption. In Bangladesh, milk is produced mostly in nonorganized way and usually it is supplied to the consumers from the urban and rural areas by milk men (Khan et al., 2008). Very limited number of research works has been carried out in our country regarding the milk quality and extensive research work is needed based on the quality of milk produced in different areas of Bangladesh. The evaluation of raw milk in different areas of our country would give valuable information for enhancing our knowledge about milk quality. Therefore, the present research work was undertaken to know the milk quality and detect the level of adulterant in raw milk collected from different local markets in Mymensingh town.

\section{Materials and methods}

\section{Collection of samples}

Raw milk samples were collected from five different markets of Mymensingh sadar. Five samples were collected randomly from each of Bhangnamari bazaar, Sutiakhali bazaar, Vabokhali bazaar, Shombhuganj bazaar and Mymensingh sadar bazaar. The samples were immediately cooled in ice box containing ice packs. The milk was analyzed in the laboratory within 2 hours after arrival.

\section{Analysis of the sample}

Specific gravity test was performed using Quevenne's Lactometer according to the procedure described by Aggarwala and Sharma (1961). Acidity test was determined by titrating with $0.1 \mathrm{~N}$ sodium hydroxide solution using the procedure of Aggarawala and Sharma (1961). Total solids $(\mathrm{g} / \mathrm{Kg})$, solids-not-fat $(\mathrm{g} / \mathrm{Kg})$ and protein tests were performed according to AOAC (2003). Fat percent was estimated by the Gerber method according to Aggarwala and Sharma (1961). In addition to, clot-on-boiling test ( $2 \mathrm{~mL}$ milk in a sterilized test tube and heated on flame until the milk was boiled), alcohol test (mixing milk and $68 \%$ ethanol with ratio $1: 1$ ), starch test (3 $\mathrm{mL}$ milk in a test tube, boiled thoroughly and added 2 to 3 drops of $1 \%$ iodine solution), sugar test $(10 \mathrm{~mL}$ milk in a test tube, added $5 \mathrm{~mL}$ of $\mathrm{HCl}$ along with $0.1 \mathrm{~g}$ of resorcinol and boiled in water bath for 5 minutes) and formalin test (10 $\mathrm{mL}$ milk taken in a test tube and added $5 \mathrm{~mL}$ conc. $\mathrm{H}_{2} \mathrm{SO}_{4}$ on the sides of the test tube without shaking) were performed.

\section{Statistical analysis}

Data were analyzed by Completely Randomized Design (CRD) using SPSS software (IBM SPSS Statistics 20). Also, Duncan Multiple Range Test (DMRT) was done to compare the treatment means as described by Gomez and Gomez (1984). The trials were done in triplicate.

\section{Results and Discussion}

\section{A. Specific gravity}

There was non-significant difference among the specific gravity values of milk samples (Table 1 ). Present research finding was supported by Eckles et al. (1951) who reported that the normal range of specific gravity of whole milk ranges from 1.027 to 1.035 with an average of 1.032 . Specific gravity obtained from Shombhuganj bazaar $(1.030 \pm 0.00)$ and Mymensingh sadar bazaars were in agrees with Bari (2001) who found that the average specific gravity of cow's milk from BAU Dairy Farm was 1.031. Again, Lateef et al. (2009) found the specific gravity of cow's milk was $1.02 \pm 0.010$. However, the results of specific gravity of milk from five sources were belongs to standard level and it clearly indicates that milk was free from water adulteration.

\section{B. Chemical parameters}

\section{Acidity (\%)}

There was non-significant difference among the acidity percentage values of milk samples (Table 1) and the highest acidity percent was observed in Sutiakhali bazaar $(0.187 \pm 0.04)$ whereas the lowest in Vabokhali bazaar $(0.150 \pm 0.03)$. The normal range of acidity of cow milk is 0.13 $0.18 \%$ lactic acid but when acidity level goes above $0.15 \%$ then it considered to be as developed acidity (Lampert, 1970). Milk of the Bhangnamari bazaar, Sutiakhali bazaar and Mymensingh sadar bazaar showed evidence of developed acidity (by 0.180 to $0.187 \%$ ) and rest were found fresh $(0.15 \%$ LA). Islam (1990) 
reported that acidity percentage of market milk was $0.14 \pm 0.010$. Again, Alam (1998) obtained $0.15 \%$ acidity of milk from AFTAB fresh raw milk. Titratable acidity is a measure of freshness and bacterial activity in milk. Popescu and Angel (2009) reported that high quality milk has more than $0.14 \%$ acidity. Higher percentage of acidity developed due to microbial activity or enzymatic reaction and here, acidity level may be slightly increased depending on the time required from milking up to receiving milk in that bazaar.

\section{Total solids content $(\mathrm{g} / \mathrm{Kg})$}

Result revealed that non-significant difference present in total solids content of milk samples collected from different local markets. Mymensingh sadar bazaar milk sample showed the highest $(126.33 \pm 12.10 \mathrm{~g} / \mathrm{Kg})$ total solids (TS) value which was statistically similar with Sutiakhali bazaar $(126.00 \pm 8.54 \mathrm{~g} / \mathrm{Kg})$ whereas the lowest value $(118.33 \pm 4.04 \mathrm{~g} / \mathrm{Kg})$ observed in Vabokhali bazaar (Table 1). Numerically TS content of all sources of milk could be remarked in the order of Mymensingh sadar bazaar > Sutiakhali bazaar > Bhangnamari bazaar > Shombhuganj bazaar > Vabokhali bazaar. This result agree with the number of research works and Islam (2006) found total-solids content of cow's milk was $142.50 \mathrm{~g} / \mathrm{Kg}$ through studying milk quality of local cows in BAU dairy farm and which is slightly higher than present study. Rahman (1992) observed that total solids content of milk collected from Manikganj chilling center and Bhagabarighat dairy plant were 11.48 and $12.91 \%$, respectively. The average total solids content of milk reported by Rahman (1992) which was similar with the TS content of present study.

\section{Fat content $(\mathrm{g} / \mathrm{Kg})$}

The mean fat content of milk was significantly $(p<0.01)$ different among the local markets of Mymensingh sadar (Table 1). The highest fat content was found in Bhangnamari bazaar whereas the lowest in Mymensingh sadar bazaar. According to legal standard of Bangladesh, milk shall contain above $3.5 \%$ fat. On the other hand, milk fat collected from Bhangnamari bazaar, Vabokhali bazaar and Sutiakhali bazaar was higher which may be due to the supply of more concentrate and dry roughage to the animal or free from water addition. This result supported by Islam (1992) who found 2.30 to $3.60 \%$ fat in market milk of Mymensingh town in Bangladesh.

\section{Solids-not-fat content $(\mathrm{g} / \mathrm{Kg})$}

There was non-significant difference among the solids-not-fat (SNF) values of milk samples (Table 1). The highest $(95.67 \pm 11.72 \mathrm{~g} / \mathrm{Kg}) \mathrm{SNF}$ value was found in Mymensingh sadar bazaar whereas the lowest $(72.93 \pm 8.78 \mathrm{~g} / \mathrm{Kg})$ observed in Bhangnamari bazaar. This variation may be due to plane of nutrition or genotype of cows. Yadav and Saraswat (1982) conducted an experiment on the market milk of different genotype and found that SNF content varies from $6.39-8.86 \%$. From this experiment, it was observed that Sutiakhali bazaar, Shombhuganj bazaar and Mymensingh sadar bazaar meet up the legal requirement of milk according to US Public Health Services (1965) who reported that milk contains minimum $8.5 \%$ solids-not-fat. Talukder (1989) found that the milk sample collected from farmers and local markets of Trishal thana under Mymensingh district were 8.61 and $7.13 \%$ SNF, respectively.

Table 1. Compositional characteristics of milk samples collected from local markets of Mymensingh sadar

\begin{tabular}{lllllll}
\hline Parameters & $\begin{array}{c}\text { Bhangnamari } \\
\text { bazaar }\end{array}$ & \multicolumn{1}{c}{$\begin{array}{c}\text { Sutiakhali } \\
\text { bazaar }\end{array}$} & $\begin{array}{c}\text { Vabokhali } \\
\text { bazaar }\end{array}$ & $\begin{array}{c}\text { Shombhuganj } \\
\text { bazaar }\end{array}$ & $\begin{array}{c}\text { Mymensingh } \\
\text { Sadar bazaar }\end{array}$ & $\begin{array}{c}\text { Level of } \\
\text { significance }\end{array}$ \\
\hline Total solids $(\mathrm{g} / \mathrm{kg})$ & $121.57 \pm 7.28$ & $126.00 \pm 8.54$ & $118.33 \pm 4.04$ & $121.00 \pm 4.04$ & $126.33 \pm 12.10$ & $\mathrm{NS}$ \\
Solids-not-fat $(\mathrm{g} / \mathrm{kg})$ & $72.93 \pm 8.78$ & $88.33 \pm 11.74$ & $79.33 \pm 6.81$ & $88.33 \pm 7.23$ & $95.67 \pm 11.72$ & $\mathrm{NS}$ \\
Protein $(\mathrm{g} / \mathrm{kg})$ & $33.42 \pm 1.83$ & $32.96 \pm 2.88$ & $34.72 \pm 2.63$ & $34.87 \pm 2.85$ & $33.93 \pm 3.01$ & $\mathrm{NS}$ \\
Fat $(\mathrm{g} / \mathrm{kg})$ & $48.66^{\mathrm{a}} \pm 3.51$ & $37.66^{\mathrm{b}} \pm 3.20$ & $39.00^{\mathrm{b}} \pm 3.61$ & $32.66^{\mathrm{c}} \pm 4.04$ & $30.66^{\mathrm{c}} \pm 4.51$ & $\mathrm{~N}$ \\
Ash $(\mathrm{g} / \mathrm{kg})$ & $6.30 \pm 0.60$ & $6.87 \pm 0.60$ & $6.73 \pm 0.50$ & $7.10 \pm 0.40$ & $7.60 \pm 0.36$ & $\mathrm{NS}$ \\
Specific gravity & $1.026 \pm 0.00$ & $1.028 \pm 0.00$ & $1.028 \pm 0.00$ & $1.030 \pm 0.001$ & $1.031 \pm 0.001$ & $\mathrm{NS}$ \\
Acidity (\%) & $0.180 \pm 0.03$ & $0.187 \pm 0.04$ & $0.150 \pm 0.03$ & $0.157 \pm 0.01$ & $0.180 \pm 0.02$ & $\mathrm{NS}$ \\
\hline
\end{tabular}

$a, b, c$ Mean values within a row having different superscripts differ significantly. ${ }^{* \star}$ Significant at $p<0.01 ;$ NS, Non significant ( $\left.p>0.05\right)$. 


\section{Protein content $(\mathbf{g} / \mathbf{K g})$}

The protein content of milk samples collected from different local markets showed nonsignificant difference. The highest $(34.87 \pm 2.85$ $\mathrm{g} / \mathrm{Kg}$ ) protein value was found in Shombhuganj bazaar which was almost similar to Vabokhali bazaar $(34.72 \pm 2.63 \mathrm{~g} / \mathrm{Kg})$ and the lowest $(32.96 \pm 2.88 \mathrm{~g} / \mathrm{Kg})$ in Sutiakhali bazaar (Table 1$)$. This finding was quite similar with Hossain (2009) who reported that average protein content of BAU dairy farm milk was $36.65 \mathrm{~g} / \mathrm{Kg}$.

\section{Ash content $(\mathrm{g} / \mathrm{Kg})$}

Statistical analysis showed that non-significant difference present among the ash values of milk samples. Mymensingh sadar bazaar (7.60 0.36 $\mathrm{g} / \mathrm{Kg}$ ) milk sample showed the highest ash value which was nearly similar with Shombhuganj bazaar (7.10 \pm 0.40$)$ and the lowest observed in Bhangnamari bazaar $(6.30 \pm 0.60 \mathrm{~g} / \mathrm{Kg})$ (Table 1). This finding was similar to Amin (2005) who reported that average ash content of milk in Mymensingh town was $6.78 \mathrm{~g} / \mathrm{kg}$.

\section{Adulteration tests}

\section{Clot-on-boiling test (COB)}

The entire milk samples collected from Bhangnamari bazaar, Sutiakhali bazaar, Vabokhali bazaar, Shombhuganj bazaar and Mymensingh sadar bazaar showed negative results of $\mathrm{COB}$ test and indicating that there was no developed acidity in milk (Table 2) which may be due to good practices in handling, keeping, transportation and storage of milk. Biswas et al. (1997) and Saha et al. (1998) found that the COB tests was negative and indicated that there was no developed acidity in milk. Bari (2001) also agree with this finding that carried out a research work on comparative study of platform tests on milk in the local markets and found negative result of COB.

\section{Alcohol test}

Alcohol test showed negative results on milk sample collected from different local markets of Mymensingh sadar (Table 2). This finding agrees with Bari (2001) who carried out a research work on comparative study of platform tests on milk in the local markets and found negative result of alcohol test. Milk coagulated only when the acidity of milk reached $0.21-0.23 \%$ but this research acidity level belongs to $0.150-0.187 \%$. That's why results of alcohol test for different local markets indicate milk of better quality in Mymensingh sadar.

\section{Starch test}

The results for starch test of milk sample collected from local markets of Mymensingh sadar showed negative results (Table 2). Islam et al. (2013) obtained similar results in the milk samples collected from Muktagacha upazila. Starch is added in milk as adulterant and due to addition of starch increases SNF content in milk as well as reduces fat percentage in milk. However, as the entire milk samples showed negative result so, it might be said that there was no starch added in milk samples.

\section{Formalin test}

The entire milk samples collected from Bhangnamari bazaar, Sutiakhali bazaar, Vabokhali bazaar, Shombhuganj bazaar and Mymensingh sadar bazaar showed negative results of formalin test which indicates that milk was not preserved with formalin $(40 \%$ solution of formaldehyde). Islam (2013) also found similar results through studying milk samples from local markets of Madhupur upazila in Tangail district.

Table 2. Adulteration test of milk sample collected from five local markets

\begin{tabular}{lccccc}
\hline \multirow{2}{*}{ Adulteration test } & \multicolumn{4}{c}{ Markets } \\
\cline { 2 - 6 } & $\begin{array}{c}\text { Bhangnamari } \\
\text { bazaar }\end{array}$ & $\begin{array}{c}\text { Sutiakhali } \\
\text { bazaar }\end{array}$ & $\begin{array}{c}\text { Vabokhali } \\
\text { bazaar }\end{array}$ & $\begin{array}{c}\text { Shombhuganj } \\
\text { bazaar }\end{array}$ & $\begin{array}{c}\text { Mymensingh } \\
\text { Sadar bazaar }\end{array}$ \\
\hline Clot-on-boiling test & Negative & Negative & Negative & Negative & Negative \\
Alcohol test & Negative & Negative & Negative & Negative & Negative \\
Starch test & Negative & Negative & Negative & Negative & Negative \\
Formalin test & Negative & Negative & Negative & Negative & Negative \\
Sugar test & Negative & Negative & Negative & Negative & Negative \\
\hline
\end{tabular}




\section{Sugar test}

Milk samples collected from Bhangnamari bazaar, Sutiakhali bazaar, Vabokhali bazaar, Shombhuganj bazaar and Mymensingh sadar bazaar showed negative results for sugar test. It may be said that sucrose was not added to the milk.

\section{Conclusion}

From chemical parameters, it was found that the tested milk samples of local markets showed significant differences $(p<0.01)$ regarding to the fat content in milk. Statistically non-significant differences $(p>0.05)$ were found among the specific gravity, acidity, total solids, solids-not-fat, protein and ash content of milk samples. Research findings revealed that milk qualities of local markets were in fair except slight adulteration and

\section{References}

Aggarwala AC, Sharma RM (1961). A Laboratory Manual of Milk Inspection. $4^{\text {th }}$ edition. Asia Publishing House. Bombay, Kolkata, New Delhi, India.

Alam MM (1998). Study on the quality of raw milk produced by individual farmers and mixed milk collected from different centres of four Thana of Kishoregonj district under Aftab Bahumukhi Farm Limited. MS Thesis, Department of Dairy Science, Bangladesh Agricultural University, Mymensingh.

AOAC (2003). Official Methods of Analysis. $15^{\text {th }}$ edition. Association of Official Analytical Chemists, Arlington, Virginia, USA.

Asaduzzaman (2000). To detect the adulteration of milk obtained from Bangladesh Agricultural University, Mymensingh dairy farm and local markets. MS Thesis, Department of Dairy Science, Bangladesh Agricultural University, Mymensingh.

Bari AKML (2001). Comparative study of platform tests on milk in the local markets and Bangladesh Agricultural University dairy farm. MS Thesis, Department of Dairy Science, Bangladesh Agricultural University, Mymensingh.

Biswas AKMAH, Hassan MN, Islam, MN (1997). Effect of Banana (Musa sapientum) leaf on the keeping quality of raw milk. MS Thesis, the rate of adulteration was relatively low in Bhangnamari bazaar whereas high in Vabokhali bazaar due to low total solids contents. Fat content in milk from Shombhuganj bazaar and Mymensingh sadar bazaar revealed much lower compared to other markets and it implies that there was a maximum possibility of adulteration in milk with addition of water or rising fat from the milk. Result also clearly indicated that there was no adulteration in milk with poisonous materials like formalin and unwanted materials like sugar and starch. However, decreasing the milk adulteration by adding water, removing fat or others would be possible through motivation of farmers or producers by giving proper training or extension activities. So, steps should be taken for the consumers as well as farmers to develop their knowledge about the quality and identity of good quality milk.

Department of Dairy Science, Bangladesh Agricultural University, Mymensingh.

Eckles CH, Conbs WB, Maey H (1951). Milk and milk products. $4^{\text {th }}$ edition. McGrow-Hill Book Company. New York, USA.

FDA (1995). Defect Action Level Handbook. Center for Food Safety and Applied Nutrition. Washington, DC.

Gomez KA, Gomez AK (1984). Statistical procedures for Agricultural Research. $2^{\text {nd }}$ Edition John Wiley and Sons. New York, Chickester, Brisbane, Toronto, Singapore. Pp. 207-215.

Haasnoot W, Smiths NGE, Kemmers-Voncken AEM, Bremer MGE (2004). Fast biosensor immunoassays in milk of ewe and goats. Journal of Dairy Science, 71: 322-329.

Hossain MS (2009). Effect of milk production and milk composition of early lactating cows by supplementation of rice powder with concentrate. MS Thesis, Department of Dairy Science, Bangladesh Agricultural University, Mymensingh.

Islam KMA (1990). A study on the milk yield, composition and energy value of indigenous cow's milk at surrounding villages of Manikgonj Milk Chilling Centre, Milk Vita Manikgonj. MS Thesis. Department of Dairy 


\section{Adulteration of raw milk at Mymensingh town}

Science, Bangladesh Agricultural University, Mymensingh.

Islam MA (1992). A comparative economic analysis of milch cows and buffalo's in two selected village of Mymensingh district in Bangladesh. MS Thesis, Department of Agricultural Finance, Bangladesh Agricultural University, Mymensingh.

Islam MA (2013). Quality evaluation and detection of adulteration of raw milk collected from local markets at Madhupur upazila of Tangail district. MS Thesis, Department of Dairy Science, Bangladesh Agricultural University, Mymensingh.

Islam MA, Rashid MH, Kajal MFI, Alam MS (2013). Quality of milk available at local markets of Muktagacha upazila in Mymensingh district. Journal of Bangladesh Agricultural University, 11(1): 119-124.

Islam MR (2006). Milk yield and quality of different genotype of dairy cows of BAU dairy farm. MS Thesis, Department of Dairy Science, Bangladesh Agricultural University, Mymensingh.

Khan MTG, Zinnah MA, Siddique MP, Rashid MH, Islam MA, Choudhury KA (2008). Physical and microbial qualities of raw milk collected from Bangladesh Agricultural University dairy farm and the surrounding villages. Bangladesh Journal of Veterinary Medicine, 6: 217-221

Lampert IM (1970). Modern Dairy Production. $3^{\text {rd }}$ Edition. Chemical Publishing Company. Inc. New York.

Lateef MA, Faraz MI, Mustafa P, Akthar ABMK (2009). Detection of adulterants and chemical composition of milk supplied to canteens of various hospitals in Faisalabad city. Pakistan Journal of Zoolology, 9: 139142.

Marcus IA (1979). Disease prevention in America: From a local to a national outlook, 1880-
1910. Bulletin of the History of Medicine, 53: 184-203.

Nicolaou N, Xu Y, Goodacre R (2011). MALDI-MS and multivariate analysis for the detection and quantification of different milk species. Bio-analytical Chemistry, 399: 3491-3502.

O'Mahony F (1988). Rural Dairy Technology: Experiences in Ethiopia. ILRI (aka ILCA and ILRAD), Addis Ababa, Ethiopia, ISBN13:9789290530923. Pp. 64.

Popescu A, Angel E (2009). Analysis of milk quality and its importance for milk processors. Lucrari Stiintifice Zootechnie Si Biotechnologii, 42: 501-503.

Rahman MS (1992). Dairy Development in Bangladesh. Proceeding of $4^{\text {th }}$ National Conference. Bangladesh Animal Husbandry Association. Pp. 84- 88.

Saha BK, Islam MN, Mannan AKMA (1998). Studies on the preservatives of raw milk with $\left(\mathrm{H}_{2} \mathrm{O}_{2}\right)$ and sodium bicarbonate $\left(\mathrm{NaHCO}_{3}\right)$ for rural dairy farmers. MS Thesis, Department of Dairy Science, Bangladesh Agricultural University, Mymensingh.

Salam AM (1993). The studies on the physical, chemical and microbiological qualities of milk produced in Baghabarighat Milk Shed Area. MS Thesis, Department of Dairy Science, Bangladesh Agricultural University, Mymensingh.

Talukder OGM (1989). A study on physical and chemical qualities of milk collected from different markets and villages of Trisal upazila. MS Thesis, Department of Dairy Science, Bangladesh Agricultural University, Mymensingh.

US Public Health Service (1965). Grade A Pasteurized Milk Ordinance.

Yadav AN, Saraswat BL (1982). Note on the physical and chemicals qualities of market in Varanasi town, India. Asian Journal Research, 1(1): 74-76. 